\title{
GÊNERO E SEXUALIDADE NO AMBIENTE ESCOLAR: CONCEPÇÕES DAS DIRETORAS FRENTE A PRECONCEITOS E DISCRIMINAÇÕES COM ESTUDANTES LGBTTS
}

Gabriela da Silva ${ }^{1}$

A pesquisa em nível de mestrado procurou responder à seguinte questão: - Qual a importância que as dimensões de gênero e sexualidade adquirem na concepção das diretoras escolares no reconhecimento ou desconhecimento da discriminação e do preconceito em relação a lésbicas, gays, bissexuais, transexuais e transgêneros (LGBTT)? O objetivo geral foi pesquisar as concepções das diretoras atuantes na rede municipal de educação - Tubarão sobre preconceitos e discriminações relacionados aos sujeitos que não tem uma correspondência entre sexo biológico, identidade de gênero e expressão da sexualidade socialmente esperados. Como objetivos específicos o estudo se propôs identificar as concepções das diretoras sobre questões de gênero, sexo e sexualidade; evidenciar a existência do preconceito e discriminação para com alunos LGBTT na concepção das diretoras; analisar o posicionamento das diretoras frente a atitudes de preconceitos e discriminação por parte dos alunos, funcionários e professores. Os referenciais teóricos pautaram-se nos aportes dialéticos, culturalistas, identitárias e das diferenças. Os "Estudos Queer" contribuíram para a compreensão da escola como possível espaço de subversão das normas de gênero/sexo, superando as propostas que fixam os sujeitos em estruturas rígidas, deterministas e convencionais. A pesquisa teve como lócus o ambiente escolar da rede municipal de ensino de Tubarão, compreendendo seis das oito unidades escolares que oferecem as séries finais do ensino fundamental. A metodologia foi realizada por meio de entrevistas semiestruturadas com seis diretoras de escola. Com relação aos resultados, observou-se que as discriminações

\footnotetext{
Submetido em: 18/01/2019

Aceito em: 18/01/2019

Publicado em: 01/06/2019

1 Doutoranda em Educação PPGE/UFSC linha de pesquisa Sujeitos. Processos Educativos e Docência/Ensino e Formação de Professores. Co-fundadora do NeTrans.
} 
e preconceitos surgidos no espaço escolar ou são encaminhadas por um trabalho pontual e não sistemático, ou se reduzem a sermões que envolvem o poder atribuído à diretora na exigência do respeito às diferenças. A sexualidade é vista como atrelada ao sexo biológico, e os casais heterossexuais são vistos como extensão da ideia de reprodução e pelo viés da prevenção a DSTs/HIV/AIDS. Identificou-se uma lacuna na formação inicial e continuada das diretoras com temáticas que envolvam o universo das diferenças sexuais e de gênero, de forma que a discussão na escola é atribuída aos profissionais da área da saúde. Neste sentido, é imprescindível destacar o desafio da escola na luta pela transformação de ideologias conservadoras e dominantes, ainda heteronormativa, que excluem meninas e meninos por suas identidades de gênero e sexual e lutar pelo compromisso da escola em "educar" para as questões humanas, e entre elas as referentes à sexualidade e ao gênero.

Palavras-chave: Educação. Formação Humana. Diretoras. Gênero. Sexualidade.

Dissertação disponível em:

https://riuni.unisul.br/bitstream/handle/12345/585/110144_Jesualdo.pdf?sequence=1\&is Allowed=y 